\title{
Pengaruh Budaya Organisasi Dengan Pendekatan Integritas, Etos Dan Lingkungan Kerja Terhadap Kinerja Organisasi
}

\author{
Sayekti Suindyah Dwiningwarni ${ }^{1 *}$, Prince Dindah ${ }^{2}$ \\ Universitas Darul 'Ulum Jombang ${ }^{1}$, Sekertariat DPRD Jombang ${ }^{1}$ \\ *Korespondensi: dyah_susanti67@yahoo.co.id
}

Diserahkan: 22 Mei 2017, Direvisis: 1 Agustus 2017 Diterima: 31 Agustus 2017

\begin{abstract}
s
The purpose of this research is to know the influence of integrity dimension of organizational culture, work ethic and work environment to organizational performance. The research type is descriptive with quantitative approach, with permanent employee population / civil servant (PNS) and honorary at secretariat of DPRD Jombang regency. The sample used as the respondent is 27 people. Data analysis techniques use simple linear regression analysis and multiple linear regression analysis, $t$-test and F-test to test the applicable hypothesis. Based on result of data analysis known that: 1) dimension of organizational culture culture of integrity and real positive influence to organizational performance; 2) Dimension of work ethic variable of organizational culture and real positive effect on organizational performance; 3) Dimension of organizational culture variable and work environment have real positive effect on organizational performance; 4) The dimensions of organizational culture culture of integrity, work ethic and work environment simultaneously and a real positive impact on organizational performance; 5) The dimensions of organizational culture variables on dominant integrity affect the performance of the organization.
\end{abstract}

Keywords: Organizational Culture And Performance, Integrity, Work Ethic And

Environment

\begin{abstract}
Abstrak
Tujuan dari penelitian ini adalah untuk mengetahui pengaruh integritas dimensi budaya organisasi, etos kerja dan lingkungan kerja terhadap kinerja organisasi. Jenis penelitian adalah deskriptif dengan pendekatan kuantitatif, dengan populasi pegawai tetap/Pegawai Negeri Sipil (PNS) dan honorer pada sekretariat DPRD Kabupaten Jombang. Sampel yang digunakan sebagai responden sebanyak 27 orang. Teknik analisa data menggunakan analisa regresi linear sederhana dan analisa regresi linear berganda, Uji-t serta Uji -F untuk menguji hipotesis yang berlaku. Berdasarkan hasil analisis data diketahui bahwa: 1) dimensi variabel budaya organisasi integritas dan pengaruh positif yang nyata terhadap kinerja organisasi; 2) Dimensi variabel etik kerja budaya organisasi dan pengaruh positif yang nyata terhadap kinerja organisasi; 3) Dimensi variabel budaya organisasi dan lingkungan kerja berpengaruh positif nyata terhadap kinerja organisasi; 4) Dimensi variabel budaya organisasi integritas, etos kerja dan lingkungan kerja secara bersamaan dan pengaruh positif yang nyata terhadap kinerja organisasi; 5) Dimensi variabel budaya organisasi terhadap integritas dominan berpengaruh terhadap kinerja organisasi.
\end{abstract}

Kata kunci: Budaya Dan Kinerja Organisasi, Integritas, Etos Kerja Dan Lingkungan

\section{A. PENDAHULUAN}

Sebuah organisasi agar tetap eksis maka harus berani menghadapi tantangan dan implikasinya yaitu menghadapi perubahan dan memenangkan persaingan. Sumber daya yang dimiliki oleh organisasi seperti dana/ modal, metode dan mesin tidak bisa memberikan hasil yang maksimal apabila tidak didukung oleh nilai, sistem , prosedur dan sumber daya manusia yang mempunyai kinerja yang optimum. Berbagai kebijakan pemerintah untuk terus-menerus memperbaiki pelayanan publik kepada masyarakat. Diantaranya adalah upaya melakukan pelayanan prima. Untuk memujudkan kinerja 
terutama oleh lembaga pelayanan publik yang optimal yang tepat guna dan sasaran maka perlu beberapa hal yang diperhatikan diantaranya masalah budaya organisasi.

Menurut Sarplin dalam Susanto (2006) dalam (Awadh \& Saad 2013) budaya oganisasi adalah suatu sistem nilai, kepercayaan dan kebiasaan dalam suatu organisasi yang saling berinteraksi dengan struktur sistem formalnya untuk menghasilkan normanorma perilaku organisasi. Menurut Ivancevich (2006) dalam (Liao \& Huang 2016) budaya organisasi yang kuat dicirikan dengan adanya karyawan yang memiliki nilai inti bersama. Semakin banyak nilai berbagi dan menerima nilai inti, semakin kuat budaya, dan semakin besar pengaruhya terhadap perilaku organisasi.

Kinerja karyawan adalah perilaku nyata yang ditampilkan setiap karyawan sebagai prestasi kerja yang dihasilkan sesuai dengan perannya dalam perusahaan (Rivai,2004). Salah satu faktor yang dapat mempengaruhi kinerja karyawan adalah kepuasan kerja. Kepuasan kerja merupakan merupakan sikap umum individu terhadap pekerjaannya atau penilaian karyawan atas seberapa puas atau tidak puas dirinya dengan pekerjaannya ((Robbins,2006).

Pemerintah Daerah adalah Gubernur, Bupati, atau Walikota, dan perangkat daerah sebagai unsur penyelenggara pemerintah daerah. (UU RI Nomor 32 Tahun 2004:4). Kinerja pemerintah daerah adalah sebagai keseluruhan pencapaian hasil yang telah diraih dan telah dicapai oleh pemerintah daerah dalam menangani keseluruhan kegiatan yang dilakukan oleh pemerintah daerah dalam satu periode tertentu (Fadel, 2008).

Penelitian ini dilakukan di dalam sebuah organisasi Pemerintahan, dengan alasan sebagai berikut: (1) organisasi pemerintahan pegawainya ada dua macam, yaitu Pegawai Negeri Sipil dan kontrak; (2) Pengukuran kinerja organisasi dalam organisasi pemerintahan akan berbeda dengan dengan organisasi swasta, hal ini dikarenan jika dan hanya jika dalam organisasi pemerintahan pengukuran kinerja didasarkan pada DP3 pegawai dan pegawai swasta pengukuran kinerjanya berdasarkan pada produktivitas pegawainya. (3) perbedaan dalam poin (2) tersebut yang menyebabkan peneliti tertarik untuk melakukan penelitian ini.

Penelitian budaya organisasi dan kinerja organisasi dapat juga dilakukan di lingkungan Sekretariat DPRD Kabupaten Jombang. Sekretariat DPRD Kabupaten Jombang sebagai bagian dari pelaksana Pemerintah Daerah terus berupaya melakukan pembenahan di bidang layanan dalam rangka capain kerja lembaganya. Beberapa hal yang mendukung pencapaian tersebut diantaranya adalah dengan mengkorelasi pengaruh budaya organisasi terhadap kinerjanya. DPRD Kabupaten Jombang mempunyai 50 anggota yang terdiri dari berbagai partai politik yang telah memenangkan perolehan suara dalam pemilu anggota DPR, DPD, DPRD Provinsi dan Kabupaten/Kota pada tahun 2014. Jabatan anggota DPRD Kabupeten Jombang selama 5 (lima) tahun yaitu tahun 2014 sampai dengan tahun 2019. Jumlah anggota DPRD Kabupaten Jombang menurut jenis kelamin dan partai politiknya dapat dilihat pada Tabel berikut ini: 
Tabel 1. Jumlah Anggota DPRD Kabupaten Jombang Menurut Jenis Kelamin Dan Partai Politik Tahun 2014

\begin{tabular}{|c|c|c|c|c|}
\hline NO & PARTAI & LAKI-LAKI & PEREMPUAN & JUMLAH \\
\hline 1 & PDIP & 8 orang & 1 orang & 9 orang \\
\hline 2 & PKB & 5 orang & 3 orang & 8 orang \\
\hline 3 & PARTAI GOLKAR & 4 orang & 3 Orang & 7 orang \\
\hline 4 & PARTAI DEMOKRAT & 3 orang & 3 orang & 6 orang \\
\hline 5 & PKS & 5 orang & - & 5 orang \\
\hline 6 & PARTAI NASDEM & 4 orang & - & 4 orang \\
\hline 7 & PPP & 4 orang & - & 4 orang \\
\hline 8 & PAN & 3 orang & - & 3 orang \\
\hline 9 & PARTAI HANURA & 3 orang & - & 3 orang \\
\hline \multirow[t]{2}{*}{10} & PARTAI GERINDRA & 1 orang & - & 1 orang \\
\hline & JUMLAH & 50 orang & 10 orang & 50 orang \\
\hline
\end{tabular}

Sumber : Sekretariat DPRD Kabupaten Jombang

Alat kelengkapan DPRD Kabupaten Jombang, antara lain: 1. Komisi-komisi terdiri dari 5 (lima) komisi, yaitu Komisi A (bidang Pemerintahan), Komisi B (bidang Perekonomian dan Keuangan), Komisi C (bidang Pembangunan), Komisi D (Bidang Kesejahteraan Rakyat); 2. Badan Kehormatan DPRD; 3. Badan Musyawarah DPRD; 4. Badan Anggaran DPRD. Selain itu, anggota DPRD Kabupaten Jombang juga dibagi dalam 8 (delapan) fraksi, antara lain: 1. PDI Perjuangan; 2. PKB; 3. Golkar; 4. Demokrat; 5. PKS; 6. Nasdem; 7. PPP; 8. Hanura. (Sekretariat DPRD Kabupaten Jombang, 2014:2).

Anggota DPRD dalam melaksanakan kegiatan sehari-harinya dibantu oleh sekretariat DPRD yang dikepalai oleh seorang sekretaris yang berstatus sebagai Pegawai Negeri Sipil (PNS). Dalam Sekretariatan DPRD Kabupaten Jombang, seorang sekeretaris dalam menjalankan tugasnya dibantu oleh para pegawai yang bearstatus PNS dan Non PNS dengan jumlah sebanyak 50 orang, dengan susunan sebagai berikut:

Tabel 2. Jumlah Dan Susunan Pegawai Di Lingkungan Sekretariat DPRD Kabupaten Jombang Tahun 2014

\begin{tabular}{|c|c|c|}
\hline No & Jabatan & Jumlah \\
\hline 1 & Sekretaris Dewan & 1 orang \\
\hline 2 & Kepala Bagian & 5 orang \\
\hline 3 & Kepala seksi & 6 orang \\
\hline 4 & Staf PNS & 26 orang \\
\hline 5 & Tenaga Kontrak & 15 orang \\
\hline & Jumlah & 54 orang \\
\hline
\end{tabular}

Sumber: Sekretariat DPRD Kabupaten Jombang

Salah satu pengukuran kinerja para pegawai di lingkungan sekretariat DPRD Kabupaten Jombang adalah jam kerja. Jam kerja pegawai sekretariat DPRD Kabupaten Jombang dimulai jam 07.00 sampai dengan 16.00 WIB.

Tujuan dalam penelitian ini antara lain: (1) Pengaruh budaya organisasi yang berdimensi integritas, etos dan lingkungan kerja terhadap kinerja organisasi di lingkungan Sekretariat DPRD Kabupaten Jombang secara partial; (2) Pengaruh budaya organisasi yang berdimensi integritas, etos dan lingkungan kerja terhadap kinerja organisasi di lingkungan Sekretariat DPRD Kabupaten Jombang secara serempak. 
Hipotesis dalam penelitian ini antara lain: (1) Diduga ada pengaruh yang postif dan nyata antara budaya organisasi yang berdimensi integritas, etos dan lingkungan kerja terhadap kinerja organisasi di lingkungan Sekretariat DPRD Kabupaten Jombang secara partial; (2) Diduga ada pengaruh yang postif dan nyata antara budaya organisasi yang berdimensi integritas, etos dan lingkungan kerja terhadap kinerja organisasi di lingkungan Sekretariat DPRD Kabupaten Jombang secara serempak.

\section{B. LANDASAN TEORI}

\section{Budaya Organisasi}

Budaya organisasi adalah sistem makna bersama yang dianut oleh anggotaanggota yang membedakan organisasi itu dari organisasi-organisasi lain ((Robbins 2013). Stoner et al (2002) dalam (Hatane 2015) menyatakan bahwa budaya (culture) merupakan gabungan kompleks dari asumsi, tingkah laku, cerita, mitos, metafora dan berbagai ide lain yang menjadi satu untuk menentukan apa arti menjadi anggota masyarakat tertentu. Sedangkan budaya organisasi (organizational culture) merupakan sejumlah pemahaman penting, seperti norma sikap, dan keyakinan, yang dimiliki bersama oleh anggota organisasi.

Hofstede (1994) dalam (Awadh \& Saad 2013) mendefinisikan budaya organisasi sebagai keseluruhan pola pemikiran, perasaan dan tindakan dari suatu kelompok sosial yang membedakan dengan kelompok sosial yang lain. Atribut yang berbeda budaya telah diatur atas dasar norma-norma dan sikap yang membantu dalam membedakan satu perusahaan dari yang lain. (Forehand and von Gilmer, 1964) dalam (Awadh \& Saad 2013). karakteristik tertentu budaya organisasi telah dibentuk dalam yang mengatur norma, nilai-nilai dan keyakinan membantu dalam sempurna hubungan antara Mereka. (Hodgetts and Luthans, 2003) dalam (Awadh \& Saad 2013).

Hasil penelitian yang dilakukan (Widyaningrum 2012) ini memiliki kontribusi yang baik kepada manajemen humanresources dan manageme praktis nt dan juga dapat digunakan sebagai dasar untuk lebih lanjut penelitian, terutama mengenai organizational culture, kemampuan, organizationalcommitment dan kinerja karyawan. Hasil Penelitian yang dilakukan (Bagus Ida ,Astika, Putra 2016) menunjukkan bahwa motivasi, budaya organisasi, dan spiritualitas berpengaruh positif terhadap kinerja pegawai. Penelitian selanjutnya dapat menggunakan atasan pegawai sebagai responden dan eksplorasi lebih lanjut mengenai spiritualitas.

\section{Kinerja Organisasi}

Hasibuan dalam Sujak (1990) dan Sutiadi (2003) mengemukakan bahwa kinerja adalah suatu hasil kerja yang dicapai seorang dalam melaksanakan tugas-tugas yang dibebankan kepadanya yang didasarkan atas kecakapan, pengalaman dan kesungguhan serta waktu. Dengan kata lain bahwa kinerja adalah hasil kerja yang dicapai oleh seseorang dalam melaksanakan tugas yang diberikan kepadanya sesuai dengan kriteria yang ditetapkan.

Terdapat tiga faktor yang mempengaruhi kinerja karyawan individual, yaitu: (1) kemampuan individu dalam melaksanakan pekerjaan tersebut; (2) tingkat usaha yang dilakukan; serta (3) dukungan organisasi (Mathis dan Jackson, 2006) (Melina Taurisa \& Ratnawati 2012). Hasil penelitian yang dilakukan oleh (Melina Taurisa \& Ratnawati 2012) ini membuktikan dan memberi kesimpulan bahwa: (1) budaya organisasi berpengaruh positif dan signifikan terhadap kepuasan kerja, (2) budaya organisasi berpengaruh positif dan signifikan terhadap komitmen organisasional, (3) kepuasan kerja berpengaruh positif dan signifikan terhadap komitmen organisasional, (4) 
komitmen organisasional berpengaruh positif dan signifikan terhadap kinerja karyawan, (5) budaya organisasi berpengaruh positif dan signifikan terhadap kinerja karyawan, serta (6) kepuasan kerja berpengaruh positif dan signifikan terhadap kinerja karyawan.

Hasil penelitian yang dilakukan (Ida Ayu Brahmasari \& Agus Suprayetno 2008) antara lain: pertama, motivasi kerja bisa Langsung tidak terkait dengan kinerja perusahaan jika tidak terhubung dengan kepuasan kerja karyawan variabel. Kedua adalah bahwa kesimpulan leaderhip berhubungan negatif dengan pekerjaan karyawan kepuasan.

\section{Kerangka Pikir}

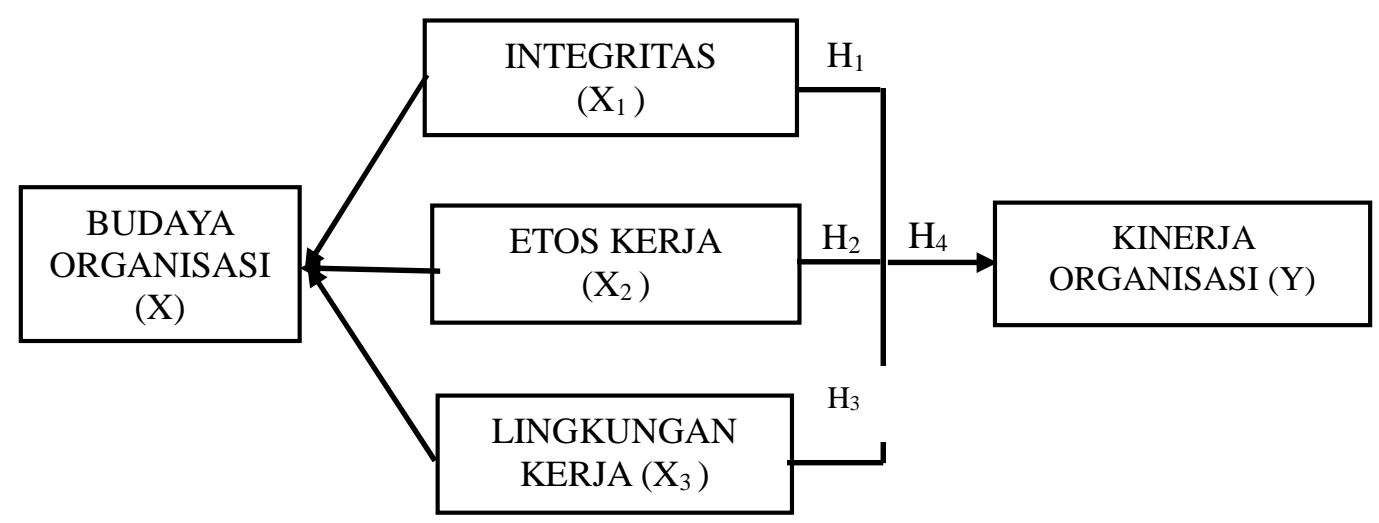

\section{Gambar 1. Rancangan Kegiatan Penelitian}

Keterangan:

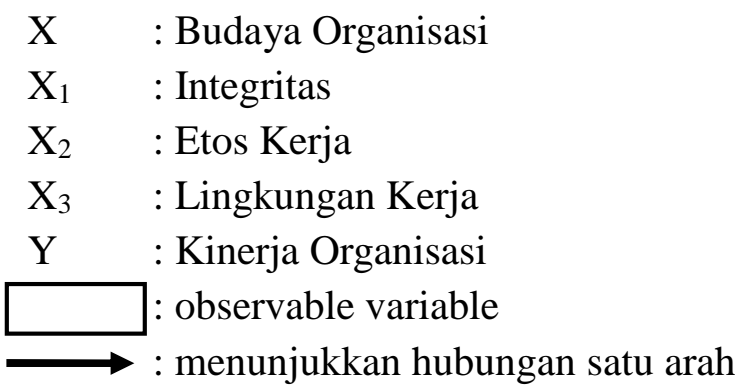

Sumber: $\quad$ Deshpande \& Farley, (1999), Cheki (1996), Xenikou \& Fernham (1996), Robbins (2006), dan Stout (1993),

\section{Hipotesis}

Berdasarkan kajian teori yang telah disampaikan serta kerangka piker diatas, maka hipotesis yang dikemukakan pada penelitian ini adalah: Diduga ada pengaruh yang postif dan nyata antara budaya organisasi yang berdimensi integritas, etos dan lingkungan kerja terhadap kinerja organisasi di lingkungan Sekretariat DPRD Kabupaten Jombang baik secara partial maupun serempak. 


\section{METODE PENELITIAN}

\section{Jenis Penelitian}

Penelitian yang dilakukan di lingkungan Sekretariat DPRD Kabupaten Jombang ini adalah penelitian deskriptif dengan pendekatan kuantitatif. Subyek sekaligus populasi dalam penelitian ini adalah pegawai sekretariat DPRD Kabupaten Jombang yang berjumlah 54 orang yang terdiri dari Pegawai Negeri Sipili sebanyak 39 orang dan tenaga kontrak sebanyak 15 orang. Sedangkan sampel yang terlibat sebanyak 27 responden dengan rincian sebagai berikut:

Tabel 3: Jumlah Responden Berdasarkan Pangkat/Golongan

\begin{tabular}{lrr}
\hline \multicolumn{1}{c}{ Pangkat / Golongan } & $\begin{array}{c}\text { Jumlah Responden } \\
\text { (orang) }\end{array}$ & Persentase (\%) \\
\hline Pembina (IV/a) & 1 & 3,70 \\
Penata TK 1 (IV/b) & 4 & 14,81 \\
Penata TK 1 (III/d) & 3 & 11,11 \\
Penata (III/c) & 2 & 7,41 \\
Penata Muda TK 1 (III/b) & 4 & 14,81 \\
Penata Muda (III/a) & 2 & 7,41 \\
Pengatur TK 1/(II/d) & 1 & 3,70 \\
Pengatur Muda TK 1 (II/b) & 3 & 11,11 \\
Pengatur Muda (II/a) & 2 & 7,41 \\
Kontrak $\quad 5$ & 18,52 \\
$\quad$ Jumlah & $\mathbf{2 7}$ & $\mathbf{9 9 , 9 9}$ \\
\hline Sumber: Data Primer dan Diolah & &
\end{tabular}

\section{Sumber Data dan Teknik Pengumpulan Data}

Sumber data yang digunakan dalam penelitian ini adalah data primer dan sekunder. Data primer diperoleh dengan mengumpulkan jawaban dari reponden dengan alat bantu kuisioner, yang berisi beberapa pertanyaan dengan beberapa opsi jawaban. Jawaban yang masuk, diukur dengan skala likert 5 (lima) poin jawaban dengan pilihan sebagai berikut : a) sangat setuju dengan nilai skor (5), b) setuju dengan nilai skor (4), c) ragu-ragu atau netral dengan nilai skor (3), d) tidak setuju dengan nilai skor (2) dan e) sangat tidak setuju dengan nilai skor (1).

Sedangkan data sekunder diperoleh dari berbagai sumber/literature antara lain buku, jurnal ilmiah dan data yang berasal dari kantor Sekretariat DPRD Kabupaten Jombang.

\section{Definisi Operasional Variabel}

Definisi operasional variabel dalam penelitian ini adalah:

1. Variabel bebas dimensi Integritas $\left(\mathrm{X}_{1}\right)$, yaitu : a) Berdedikasi tinggi, b) Kejujuran, c) Bertaqwa.

2. Variabel bebas dimensi Etos Kerja $\left(\mathrm{X}_{2}\right)$, yaitu: a) Kreativitas dan memiliki ide-ide baru, b) Kerja keras dan tepat waktu, c) bekerja secara tim dan menghargai waktu.

3. Varaibel bebas dimensi Lingkungan Kerja $\left(\mathrm{X}_{3}\right)$, yaitu: a) lingkungan yang nyaman, menyenangkan dan kondusif, b) lingkungan yang mendukung.

4. Variabel tergantung Kinerja Organisasi (Y), yaitu: a) perspektif pembelajaran, b) efktifitas organisasi, c) promosi pegawai.

Selanjutnya, data yang msuk akan dianalisa dengan menggunakan analisa deskriptif dan statistik yaitu uji uji validitas, uji reliabiltas, dan analisa regresi untuk pengujian hipotesis. 


\section{HASIL DAN PEMBAHASAN}

Sekretariat Dewan Perwakilan Rakyat Daerah (DPRD) merupakan salah satu SKPD yang di bawah naungan pemerintahan kabupaten Jombang. Sekretariat DPRD kabupaten Jombang memiliki jumlah PNS sebanyak 39 orang dan tenaga kontrak sebanyak 15 orang. (Sekretariat DPRD Kabupaten Jombang, 2014).

Dari hasil uji validitas diketahui bahwa dari ketiga variabel bebas yaitu integritas $\left(\mathrm{X}_{1}\right)$, etos kerja $\left(\mathrm{X}_{2}\right)$ dan lingkungan kerja $\left(\mathrm{X}_{3}\right)$ dinyatakan valid. Hal terebut tampak dari hasil perhitungan uji validasi pada kolom Corrected Item Total Correlation yang memperlihatkan hasil bahwa ke lima belas item atau indikator tersebut memiliki angka atau nilai di atas 0,2546. Angka 0,2546 adalah nilai $r$ tabel satu sisi, dimana degree of freedom $(\mathrm{df})=27-2$; dengan alpha (tingkat signifikansi) $=5 \%$. Hasil uji validasi atas seluruh item atau indikator tersebut menunjukkan bahwa instrumen tersebut dapat digunakan dalam penelitian ini. Langkah selanjutnya adalah melakukan uji reliabilitas.

Pengujian reliabilitas dilakukan dengan cara membandingkan antara $r$ Alpha dengan $r$ Tabel. Jika $r$ Alpha > r Tabel, maka item atau indikator tersebut adalah reliabel dan sebaliknya. Dari hasil perhitungan menunjukkan bahwa nilai r Alpha untuk seluruh item/indikator yang diteliti menunjukkan angka lebih besar dari $r$ Tabel, yaitu 0,8660 > 0,2546 .

\section{Hasil Analisis Pengaruh Integritas $\left(\mathrm{X}_{1}\right)$ Terhadap Kinerja Organisasi (Y)}

Hasil perhitungan analisis regresi linear untuk mengetahui pengaruh antara variabel bebas, integritas $\left(\mathrm{X}_{1}\right)$ terhadap variabel tergantung, kinerja organisasi $(\mathrm{Y})$, ditunjukkan dengan tabel berikut ini:

Tabel 4. Coefficients Variabel $X_{1}$ dan $Y$

\begin{tabular}{|c|c|c|c|c|c|}
\hline \multirow{2}{*}{ Model } & \multicolumn{2}{|c|}{$\begin{array}{c}\text { Unstandardized } \\
\text { Coefficients }\end{array}$} & $\begin{array}{l}\text { Standardize } \\
\text { Coefficients }\end{array}$ & \multirow[t]{2}{*}{$\mathrm{t}$} & \multirow[t]{2}{*}{ Sig } \\
\hline & $\mathrm{B}$ & Std Error & Beta & & \\
\hline 1. (constant) & 5,591 & 1,961 & & 2,851 & 0,009 \\
\hline Integritas & 0,807 & 0,425 & 0,355 & 2,900 & 0,029 \\
\hline
\end{tabular}

Sumber:Data primer diolah

Dari tabel 4 diperoleh persamaan regresi $\mathbf{Y}=\mathbf{5 , 5 9 1}+\mathbf{0 , 8 0 7} \mathbf{X}_{\mathbf{1}}$

Hasil perhitungan nilai koefisien determinasi $\left(\mathrm{R}^{2}\right)$, Hubungan $(\mathrm{R})$ antara variabel $\mathrm{X}_{1}$ dan Y, ditunjukkan pada tabel 5 berikut ini:

Tabel 5. Model Summary

\begin{tabular}{|c|c|c|c|c|}
\hline Model & $\mathbf{R}$ & $\mathbf{R}^{2}$ & Adjusted R $\mathbf{R}^{2}$ & $\begin{array}{l}\text { Std Error of the } \\
\text { Estimate }\end{array}$ \\
\hline 1 & $0,944^{\mathrm{a}}$ & 0,892 & 0,871 & 1,084 \\
\hline
\end{tabular}

Tabel diatas menunjukkan bahwa nilai $\mathrm{R}=0,944$, ini berarti bahwa hubungan antara variabel bebas integritas $\left(\mathrm{X}_{1}\right)$ dan variabel tergantung kinerja organisasi $(\mathrm{Y})$ menunjukkan hubungan yang positif dan kuat, karena nilai $\mathrm{R}$ menunjukkan angka lebih dari $75 \%$. Selain itu nilai $\mathrm{R}^{2}=0,892$, artinya bahwa variabel kinerja organisasi $(\mathrm{Y})$ dipengaruhi oleh variabel bebas integritas $\left(\mathrm{X}_{1}\right)$ sebesar $89,20 \%$ dan sisanya $10,80 \%$ dipengaruhi oleh variabel lain di luar model. Sedangkan nilai adjusted $\mathrm{R}^{2}=0,871$, ini 
artinya variabel kinerja organisasi $(\mathrm{Y})$ dipengaruhi oleh variabel bebas integritas $\left(\mathrm{X}_{1}\right)$ sebesar $87,10 \%$ dan sisanya $12,90 \%$ dipengaruhi oleh variabel lain di luar model.

Hasil perhitungan dengan menggunakan program SPSS seperti yang tampak pada Tabel 3 (tiga) pada kolom Sig yang artinya signifikansi nilainya adalah 0,029. Nilai ini di bawah angka $\alpha$ (alpha) yaitu tingkat kesalahan 5\% atau 0,05 , yang berarti bahwa secara parsial variabel integritas $\left(\mathrm{X}_{1}\right)$ berpengaruh positif dan nyata terhadap variabel kinerja organisasi (Y). Ini berarti bahwa menolak $\mathrm{H}_{0}$ dan menerima $\mathrm{H}_{1}$.

Selain itu, bisa dengan membandingkan antara nilai $\mathrm{T}_{\text {hitung }}$ dengan $\mathrm{T}_{\text {tabel. }}$. Dimana jika nilai $\mathrm{T}_{\text {hitung }}>\mathrm{T}_{\text {tabel }}$, maka $\mathrm{H}_{1}$ diterima dan $\mathrm{H}_{0}$ ditolak. Dan sebaliknya, jika nilai $\mathrm{T}_{\text {hitung }}<\mathrm{T}_{\text {tabel }}$, maka nilai $\mathrm{H}_{0}$ diterima dan $\mathrm{H}_{1}$ ditolak. Dari hasil perhitungan nilai $\mathrm{T}_{\text {hitung }}$ diperoleh angka 2,900. Sedangkan nilai $\mathrm{T}_{\text {tabel }}$ dengan degree of freedom $(\mathrm{df})=27-2$ dan $\alpha=5 \%$ dengan pengujian dua arah (two tail test) adalah 2,060. Karena $\mathrm{T}_{\text {hitung }}>$ $\mathrm{T}_{\text {tabel }},(2,900>2,060)$, maka secara parsial variabel integritas $\left(\mathrm{X}_{1}\right)$ berpengaruh positif dan nyata terhadap variabel kinerja organisasi (Y). Ini berarti bahwa menolak $\mathrm{H}_{0}$ dan menerima $\mathrm{H}_{1}$.

\section{Hasil Analisis Pengaruh Etos Kerja ( $\left.\mathbf{X}_{2}\right)$ Terhadap Kinerja Organisasi (Y)}

Hasil perhitungan analisis regresi untuk mengetahui pengaruh antara variabel $\mathrm{X}_{2}$ terhadap variabel Y ditunjukkan pada tabel 6 berikut ini:

Tabel 6. Coefficients Variabel $X_{2}$ dan $Y$

\begin{tabular}{|c|c|c|c|c|c|}
\hline \multirow[t]{2}{*}{ Model } & \multicolumn{2}{|c|}{$\begin{array}{c}\text { Unstandardized } \\
\text { Coefficients }\end{array}$} & \multirow{2}{*}{$\begin{array}{c}\text { Standardize } \\
\text { Coefficients } \\
\text { Beta }\end{array}$} & \multirow[t]{2}{*}{$\mathrm{t}$} & \multirow[t]{2}{*}{ Sig } \\
\hline & B & Std Error & & & \\
\hline 1. (constant) & 7,118 & 2,106 & & 3,379 & 0,002 \\
\hline Etos Kerja & 0,471 & 0,453 & 0,204 & 2,640 & 0,034 \\
\hline $\begin{array}{l}\text { Dependent Variab } \\
\text { Sumber: Data Prim }\end{array}$ & anisasi & & & & \\
\hline
\end{tabular}

Tabel 6 menunjukkan bahwa hasil perhitungan analisis regresi linear sederhana antara variabel $X_{2}$ dan $Y$, diperoleh persamaan: $Y=\mathbf{7 , 1 1 8}+\mathbf{0 , 4 7 1} X_{\mathbf{2}}$ Hasil perhitungan nilai koefisien determinasi $\left(\mathrm{R}^{2}\right)$, Hubungan $(\mathrm{R})$ antara variabel $\mathrm{X}_{2}$ dan Y, ditunjukkan pada tabel 7 berikut ini:

Tabel 7. Model Summary

\begin{tabular}{ccccc}
\hline \hline Model & $\mathbf{R}$ & $\mathbf{R}^{\mathbf{2}}$ & $\begin{array}{c}\text { Adjusted } \\
\mathbf{R}^{\mathbf{2}}\end{array}$ & $\begin{array}{c}\text { Std Error of } \\
\text { the Estimate }\end{array}$ \\
\hline \hline 1 & $0,949^{\mathrm{a}} \quad 0,906$ & 0,902 & 1,136 \\
\hline \hline a.Predictors: (constant), Etos Kerja & & \\
b.Dependent Variable: kinerja organisasi \\
Sumber: Data Primer diolah
\end{tabular}

Tabel 7 menunjukkan bahwa nilai $\mathrm{R}=0,949$, ini berarti bahwa hubungan antara variabel bebas etos kerja $\left(\mathrm{X}_{2}\right)$ dan variabel tergantung kinerja organisasi $(\mathrm{Y})$ menunjukkan hubungan yang positif dan kuat, karena nilai $\mathrm{R}$ menunjukkan angka lebih dari $75 \%$. Selain itu nilai $\mathrm{R}^{2}=0,906$, artinya bahwa variabel kinerja organisasi (Y) dipengaruhi oleh variabel bebas etos kerja $\left(X_{2}\right)$ sebesar $90,60 \%$ dan sisanya $9,40 \%$ dipengaruhi oleh variabel lain di luar model. Sedangkan nilai adjusted $\mathrm{R}^{2}=0,902$, ini artinya variabel kinerja organisasi $(\mathrm{Y})$ dipengaruhi oleh variabel bebas etos kerja $\left(\mathrm{X}_{2}\right)$ sebesar 90,20\% dan sisanya 9,80\% dipengaruhi oleh variabel lain di luar model.

Hasil perhitungan dengan menggunakan program SPSS seperti yang tampak pada Tabel 6 (enam) pada kolom Sig yang artinya signifikansi nilainya adalah 0,034. Nilai ini di bawah angka $\alpha$ (alpha) yaitu tingkat kesalahan 5\% atau 0,05, yang berarti bahwa 
secara parsial variabel etos kerja $\left(\mathrm{X}_{2}\right)$ berpengaruh positif dan nyata terhadap variabel kinerja organisasi (Y). Ini berarti bahwa menolak $\mathrm{H}_{0}$ dan menerima $\mathrm{H}_{1}$.

Selain itu, bisa dengan membandingkan antara nilai $\mathrm{T}_{\text {hitung }}$ dengan $\mathrm{T}_{\text {tabel. }}$. Dimana jika nilai $\mathrm{T}_{\text {hitung }}>\mathrm{T}_{\text {tabel }}$, maka $\mathrm{H}_{1}$ diterima dan $\mathrm{H}_{0}$ ditolak. Dan sebaliknya, jika nilai $\mathrm{T}_{\text {hitung }}<\mathrm{T}_{\text {tabel }}$, maka nilai $\mathrm{H}_{0}$ diterima dan $\mathrm{H}_{1}$ ditolak. Dari hasil perhitungan nilai $\mathrm{T}_{\text {hitung }}$ diperoleh angka 2,640. Sedangkan nilai $\mathrm{T}_{\text {tabel }}$ dengan degree of freedom $(\mathrm{df})=27-2$ dan $\alpha=5 \%$ dengan pengujian dua arah (two tail test) adalah 2,060. Karena $\mathrm{T}_{\text {hitung }}>$ $\mathrm{T}_{\text {tabel }},(2,640>2,060)$, maka secara parsial variabel etos kerja $\left(\mathrm{X}_{2}\right)$ berpengaruh positif dan nyata terhadap variabel kinerja organisasi (Y). Ini berarti bahwa menolak $\mathrm{H}_{0}$ dan menerima $\mathrm{H}_{1}$.

Hasil Analisis Pengaruh Lingkungan Kerja ( $\left.\mathbf{X}_{3}\right)$ Terhadap Kinerja Organisasi (Y)

Hasil perhitungan analisis regresi untuk mengetahui pengaruh antara variabel $\mathrm{X}_{3}$ terhadap variabel Y ditunjukkan pada Tabel 8 berikut ini:

Tabel 8. Coefficients Variabel $X_{3}$ dan $Y$

\begin{tabular}{|c|c|c|c|c|c|}
\hline \multirow[t]{2}{*}{ Model } & \multicolumn{2}{|c|}{$\begin{array}{l}\text { Unstandardized } \\
\text { Coefficients }\end{array}$} & \multirow{2}{*}{$\begin{array}{c}\begin{array}{c}\text { Standardize } \\
\text { Coefficients }\end{array} \\
\text { Beta } \\
\end{array}$} & \multirow[t]{2}{*}{$\mathrm{t}$} & \multirow[t]{2}{*}{ Sig } \\
\hline & $\mathrm{B}$ & Std Error & & & \\
\hline 1. (constant) & 8,119 & 2,001 & & 4,058 & 0,000 \\
\hline Lingkungan kerja & 0,267 & 0,451 & 0,118 & 2,592 & 0,042 \\
\hline
\end{tabular}

Dependent Variabel: kinerja organisasi

Sumber: Data Primer diolah

Dari tabel 8 diperoleh hasil perhitungan analisis regresi linear sederhana antara variabel $\mathrm{X}_{3}$ dan $\mathrm{Y}$, diperoleh hasil sebagai berikut yaitu: $\mathrm{Y}=\mathbf{8 , 1 1 9}+\mathbf{0 , 2 6 7} \mathrm{X}_{3}$

Hasil perhitungan nilai koefisien determinasi $\left(\mathrm{R}^{2}\right)$, Hubungan $(\mathrm{R})$ antara variabel $\mathrm{X}_{2}$ dan Y, ditunjukkan pada Tabel 14 berikut ini:

\section{Tabel 9. Model Summary}

\begin{tabular}{|c|c|c|c|c|}
\hline Model & $\mathbf{R}$ & $\mathbf{R}^{2}$ & Adjusted $\mathbf{R}^{2}$ & $\begin{array}{l}\text { Std Error of the } \\
\text { Estimated }\end{array}$ \\
\hline $\bar{~} 1$ & $0,964^{\mathrm{a}}$ & "0,928 & "0,890 & $1,1,152$ \\
\hline
\end{tabular}

Tabel 9 menunjukkan bahwa nilai $\mathrm{R}=0,964$, ini berarti bahwa hubungan antara variabel bebas lingkungan kerja $\left(\mathrm{X}_{3}\right)$ dan variabel tergantung kinerja organisasi $(\mathrm{Y})$ menunjukkan hubungan yang positif dan kuat, karena nilai $\mathrm{R}$ menunjukkan angka lebih dari $75 \%$. Selain itu nilai $\mathrm{R}^{2}=0,928$, artinya bahwa variabel kinerja organisasi $(\mathrm{Y})$ dipengaruhi oleh variabel bebas lingkungan kerja $\left(\mathrm{X}_{3}\right)$ sebesar $92,80 \%$ dan sisanya $7,20 \%$ dipengaruhi oleh variabel lain di luar model. Sedangkan nilai adjusted $\mathrm{R}^{2}=$ 0,890 , ini artinya variabel kinerja organisasi (Y) dipengaruhi oleh variabel bebas lingkungan kerja $\left(\mathrm{X}_{3}\right)$ sebesar $89,00 \%$ dan sisanya $11,00 \%$ dipengaruhi oleh variabel lain di luar model.

Hasil perhitungan dengan menggunakan program SPSS seperti yang tampak pada Tabel 8 pada kolom Sig yang artinya signifikansi nilainya adalah 0,042. Nilai ini di bawah angka $\alpha$ (alpha) yaitu tingkat kesalahan 5\% atau 0,05, yang berarti bahwa secara parsial variabel integritas $(\mathrm{X})$ berpengaruh signifikan dan positif terhadap variabel kinerja organisasi (Y). Ini berarti bahwa menolak $\mathrm{H}_{0}$ dan menerima $\mathrm{H}_{1}$.

Selain itu, bisa dengan membandingkan antara nilai $\mathrm{T}_{\text {hitung }}$ dengan $\mathrm{T}_{\text {tabel. }}$ Dimana jika nilai $\mathrm{T}_{\text {hitung }}>\mathrm{T}_{\text {tabel }}$, maka $\mathrm{H}_{1}$ diterima dan $\mathrm{H}_{0}$ ditolak. Dan sebaliknya, jika nilai 
$\mathrm{T}_{\text {hitung }}<\mathrm{T}_{\text {tabel }}$, maka nilai $\mathrm{H}_{0}$ diterima dan $\mathrm{H}_{1}$ ditolak. Dari hasil perhitungan nilai $\mathrm{T}_{\text {hitung }}$ diperoleh angka 2,592. Sedangkan nilai $\mathrm{T}_{\text {tabel }}$ dengan degree of freedom $(\mathrm{df})=27-2$ dan $\alpha=5 \%$ dengan pengujian dua arah (two tail test) adalah 2,060. Karena $\mathrm{T}_{\text {hitung }}>$ $\mathrm{T}_{\text {tabel }},(2,592>2,060)$, maka secara parsial variabel lingkungan kerja $\left(\mathrm{X}_{3}\right)$ berpengaruh positif dan nyata terhadap variabel kinerja organisasi (Y). Ini berarti bahwa menolak $\mathrm{H}_{0}$ dan menerima $\mathrm{H}_{1}$.

\section{Pengaruh Integritas ( $\left.\mathbf{X}_{1}\right)$, Etos Kerja $\left(\mathbf{X}_{2}\right)$ dan Lingkungan Kerja $\left(\mathbf{X}_{3}\right)$ Terhadap Kinerja Organisasi (Y)}

Hasil perhitungan analisis regresi untuk mengetahui pengaruh antara variabel $\mathrm{X}_{1}$, $\mathrm{X}_{2}$, dan $\mathrm{X}_{3}$ terhadap variabel $\mathrm{Y}$ ditunjukkan pada tabel berikut ini:

Tabel 10. Coefficients Variabel $X_{1}, X_{2}, X_{3}$, dan $Y$

\begin{tabular}{|c|c|c|c|c|c|}
\hline \multirow[t]{2}{*}{ Model } & \multicolumn{2}{|c|}{$\begin{array}{l}\text { Unstandardized } \\
\text { Coefficients }\end{array}$} & \multirow{2}{*}{$\begin{array}{c}\text { Standardize } \\
\text { Coefficients } \\
\text { Beta }\end{array}$} & \multirow[t]{2}{*}{$\mathrm{t}$} & \multirow[t]{2}{*}{ Sig } \\
\hline & B & Std Error & & & \\
\hline 1. (constant) & 7,038 & 2,195 & & 3,206 & 0,004 \\
\hline Integritas & 0,793 & 1,126 & 1,230 & 2,481 & 0,021 \\
\hline Etos Kerja & 0,269 & 1,104 & 1,190 & 2,769 & 0,049 \\
\hline Lingkungan Kerja & 0,348 & 0,487 & 0,568 & 3,449 & 0,039 \\
\hline
\end{tabular}

a.Dependent Variable: Kinerja Organisasi

Sumber: Data primer diolah

Tabel diatas menunjukkan bahwa hasil perhitungan analisis regresi linear berganda antara variabel $X_{1}, X_{2}, X_{3}$ dan $Y$, adalah: $Y=\mathbf{7 , 0 3 8}+\mathbf{0 , 7 9 3} X_{1}+\mathbf{0 , 2 6 9} X_{2}+$ $\mathbf{0 , 3 4 8} \mathrm{X}_{3}$. Hasil perhitungan nilai koefisien determinasi $\left(\mathrm{R}^{2}\right)$, Hubungan $(\mathrm{R})$ antara variabel $\mathrm{X}_{1}, \mathrm{X}_{2}, \mathrm{X}_{3}$ dan $\mathrm{Y}$, ditunjukkan pada Tabel 11 berikut ini:

Tabel 11. Model Summary

\begin{tabular}{cccccc}
\hline \hline Model & $\mathbf{R}$ & $\mathbf{R}^{2}$ & Adjusted $\mathbf{R}^{\mathbf{2}}$ & $\begin{array}{c}\text { Std Error of } \\
\text { the estimate }\end{array}$ & Durbin-Watson \\
\hline 1 & $0,937^{\mathrm{a}}$ & 0,879 & 0,867 & 1,051 & 1,410 \\
\hline \hline
\end{tabular}

a.Predictors: (Constant), lingkungan kerja, etos kerja, integritas

b.Dependent Variable: Kinerja Organisasi

Sumber: Data Primer dan Diolah

Tabel 11 menunjukkan bahwa nilai $\mathrm{R}=0,937$, ini berarti bahwa hubungan antara variabel bebas integritas $\left(\mathrm{X}_{1}\right)$, etos kerja $\left(\mathrm{X}_{2}\right)$, lingkungan kerja $\left(\mathrm{X}_{3}\right)$ dan variabel tergantung kinerja organisasi (Y) menunjukkan hubungan yang positif dan kuat, karena nilai $\mathrm{R}$ menunjukkan lebih dari $75 \%$. Selain itu nilai $\mathrm{R}^{2}=0,897$, artinya bahwa variabel kinerja organisasi $(\mathrm{Y})$ dipengaruhi oleh variabel bebas integritas $\left(\mathrm{X}_{1}\right)$, etos kerja $\left(\mathrm{X}_{2}\right)$ lingkungan kerja $\left(\mathrm{X}_{3}\right)$ secara serempak sebesar $89,70 \%$ dan sisanya $10,30 \%$ dipengaruhi oleh variabel lain di luar model. Sedangkan nilai adjusted $\mathrm{R}^{2}=0,867$, ini artinya variabel kinerja organisasi $(\mathrm{Y})$ dipengaruhi oleh variabel bebas integritas $\left(\mathrm{X}_{1}\right)$, etos kerja $\left(\mathrm{X}_{2}\right)$ dan lingkungan kerja $\left(\mathrm{X}_{3}\right)$ secara serempak sebesar $86,70 \%$ dan sisanya $13,30 \%$ dipengaruhi oleh variabel lain di luar model.

Hasil pengujian hipotesis secara serempak untuk mengetahui pengaruh variabel integritas, etos kerja dan lingkungan kerja berpengaruh signifikan terhadap kinerja organisasi, adalah sebagai berikut: 
Tabel 12. Anova

\begin{tabular}{|c|c|c|c|c|c|c|}
\hline Model & & $\begin{array}{l}\text { Sum of } \\
\text { Squares }\end{array}$ & df & Mean Square & $\mathrm{F}$ & Sig. \\
\hline & Regression & 28,216 & 3 & 2,739 & 21,478 & ,039(a) \\
\hline & Residual & 5,414 & 23 & 1,105 & & \\
\hline & Total & 33,630 & 26 & & & \\
\hline \multicolumn{7}{|c|}{ a Predictors: (Constant), lingkungan kerja, etos kerja, integritas } \\
\hline \multicolumn{7}{|c|}{ b Dependent Variable: kinerja organisasi } \\
\hline Sumber: I & ta primer diol & & & & & \\
\hline
\end{tabular}

Tabel 12 menjelaskan bahwa secara bersama - sama variabel $\mathrm{X}, \mathrm{X}$ dan $\mathrm{X}$ berpengaruh positif dan nyata terhadap variabel Y. Ini dapat dilihat pada kolom Sig (signifikansi), yang memberikan nilai 0,039. Dengan taraf signifikansi yang digunakan dalam penelitian ini adalah $5 \%$, karena nilai $0,039<0,05$, maka hasil penelitian ini dapat dinyatakan menerima $\mathrm{H}_{1}$ dan menolak $\mathrm{H}_{0}$.

Atau dengan membandingkan antara nilai $F_{\text {hitung dengan }} F_{\text {tabel. }}$ Dimana jika nilai $F_{\text {hitung }}>\mathrm{F}_{\text {tabel }}$, maka $\mathrm{H}_{1}$ diterima dan $\mathrm{H}_{0}$ ditolak. Dan sebaliknya, jika nilai $\mathrm{F}_{\text {hitung }}<\mathrm{F}_{\text {tabel }}$, maka nilai $\mathrm{H}_{0}$ diterima dan $\mathrm{H}_{1}$ ditolak. Dari hasil perhitungan nilai $\mathrm{F}_{\text {hitung }}$ diperoleh angka 21,478 . Sedangkan nilai $F_{\text {tabel }}$ dengan degree of freedom $(\mathrm{df})$ untuk pembilang $=$ $27-2=25$ dan degree of freedom (df) untuk penyebut $=27-4=23$ adalah 3,42. Karena $F_{\text {hitung }}>F_{\text {tabel }},(21,478>3,42)$, maka secara serempak integritas $\left(X_{1}\right)$, etos kerja $\left(X_{2}\right)$ dan lingkungan kerja $\left(\mathrm{X}_{3}\right)$ berpengaruh positif dan nyata terhadap variabel kinerja organisasi (Y). Ini berarti bahwa menolak $\mathrm{H}_{0}$ dan menerima $\mathrm{H}_{1}$.

\section{E. PENUTUP}

Dari hasil penelitian dan pembahasan dapat disimpulkan bahwa budaya organisasi yang berdimensi integritas, etos kerja dan lingkungan kerja secara serempak berpengaruh positif dan signifikan terhadap kinerja organisasi di lingkungan Sekretariat DPRD Kabupaten Jombang. Selain itu, variabel budaya organisasi yang berdimensi integritas berpengaruh dominan terhadap kinerja organisasi ini ditunjukkan dengan nilai $\beta=0,807$ lebih besar dibandingkan dengan nilai $\beta$ untuk variabel X2 dan X3. Ini berarti bahwa variabel budaya organisasi yang berdimensi integritas merupakan variabel yang berpengaruh dominan terhadap variabel kinerja organisasi di lingkungan Sekretariat DPRD Kabupaten Jombang.

\section{DAFTAR PUSTAKA}

Awadh, A.M. \& Saad, A.M., 2013. Impact of Organizational Culture on Employee Performance. International Review of Management and Business Research, 2(1), pp.168-175. Available at: http://irmbrjournal.com/papers/1364462611.pdf.

Bagus Ida ,Astika, Putra, et al, 2016. ISSN : 2337-3067 E-Jurnal Ekonomi dan Bisnis Universitas Udayana 5 . 7 ( 2016 ): 2063-2090 Pengaruh Motivasi , Budaya Organisasi Dan Spiritualitas Pada Kinerja Pegawai Kantor Pelayanan Magister Akuntansi , Universitas Udayana, Bali , Indonesia Fakultas E. , 7, pp.2063-2090.

Hatane, S.E., 2015. Employee Satisfaction and Performance as Intervening Variables of Learning Organization on Financial Performance. Procedia - Social and Behavioral Sciences, 211, pp.619-628. Available at: http://www.sciencedirect.com/science/article/pii/S187704281505421X.

Ida Ayu Brahmasari \& Agus Suprayetno, 2008. Pengaruh Motivasi Kerja, 
Kepemimpinan dan Budaya Organisasi Terhadap Kepuasan Kerja Karyawan serta Dampaknya pada Kinerja Perusahaan (Studi kasus pada PT. Pei Hai International Wiratama Indonesia). Jurnal Manajemen dan Kewirausahaan, 10(1996), pp.pp.124-135. Available

at: http://puslit2.petra.ac.id/ejournal/index.php/man/article/view/17039.

Liao, K.-H. \& Huang, I.-S., 2016. Impact of Vision, Strategy, and Human Resource on Nonprofit Organization Service Performance. Procedia - Social and Behavioral Sciences, 224(August 2015), pp.20-27. Available at: http://dx.doi.org/10.1016/j.sbspro.2016.05.395.

Melina Taurisa, C. \& Ratnawati, I., 2012. Analisis Pengaruh Budaya Organisasi Dan Kepuasan Kerja Terhadap Komitmen Organisasional Dalam Meningkatkan Kinerja Karyawan (Studi pada PT. Sido Muncul Kaligawe Semarang). Jurnal Bisnis dan Ekonomi (JBE), 19(2), p.170187.

Robbins, S., 2013. Organizational Behavior, Available at: http://scholar.google.com/scholar?hl=en\&btnG=Search\&q=intitle:No+Title\#0.

Widyaningrum, M.E., 2012. Effects of Organizational Culture and Ability on Organizational Commitment and Performance in Ibnu Sina Hospital Gresik. , 2(1), pp.349-355. 